\title{
INTERACTION BETWEEN BIG DATA AND COMPETITION LAW IN DIGITAL SINGLE MARKET
}

\author{
Andrius Puksas ${ }^{1}$
}

\begin{abstract}
Representatives of undertakings are familiar with the importance of carefully handling and protecting personal data. However, this does not lessen the importance of improving legislation regarding data management. Both the content and quantity of information have value and potentially determine the strength of the undertakings that can access such information. This influences the constant growth in demand to improve the legal framework. The consumers and institutions responsible for consumer protection are the main initiators and stakeholders of such demand. The constant growth in the amount of preserved data more sharply raises the questions about data protection. The potential risk raises proposals enabling a competition law in data protection. The article examines such possibility in the light of digital single market. This possibility is analyzed in the light of interaction between the data protection and competition law and covers trends on enabling competition law in data protection. To ensure proper data protection, cooperation among institutions should be encouraged.
\end{abstract}

UDC Classification: 342.7 DOI: http://dx.doi.org/10.12955/cbup.v4.850

Keywords: Big data, information, competition enforcement, privacy, reform.

\section{Introduction}

Despite the traditional definition, information can be regarded the currency for services, especially for services that are publicly presented as 'free.' Such a payment method is reflected mostly on the Internet, where service providers declare the understandable need to identify the consumer and be flexible in order to provide their services. The importance of information is aptly conveyed in the widely known phrase 'who owns the information, owns the world.' This wisdom comes from the undoubted perception that information has value and greater amounts of that information can cause greater influence (for instance, higher influence in the relevant market).

Usually, the clear connection between the amounts, sensibility, and importance of provided information is expected. The more personal and sensitive information is required the more a higher protection level is expected. In most cases, customers are expecting that they need to provide only necessary information. This statement could be proven in a variety of sectors, especially in the health care and financial sectors ${ }^{2}$ (Riefa, 2015). However, these statements concerning the clear connection between the demands for data amounts and return value from the service providers cannot be held as a rule. For the majority of undertakings, the data is not only important 'here and now' but also for raw material for the possible future development of services or providing the targeted information to current and potential customers. Sometimes the possibility to gain a financial benefit from the collected data is also prudently foreseen.

The European Commission agrees with predictions that the "value of European citizens' personal data has the potential to grow to nearly $€ 1$ trillion annually by 2020" (EU Data Protection Reform and Big Data Factsheet, 2015). Such prediction-based information about the growing amounts of collected and preserved data is not only thought-provoking, but also leads to discussions about the effectiveness of data protection. In March 2014, the European Data Protection Supervisor (the EDP Supervisor) released a Preliminary Opinion of the European Data Protection Supervisor (2014) on "Privacy and competitiveness in the age of Big data: The interplay between data protection, competition law and consumer protection in the Digital Economy" (the Opinion) concerning the interaction between the 'data protection,' 'consumer protection', and 'competition.' The EDP Supervisors' Opinion 03/2013 on Purpose Limitation (2013) led to wide discussions among stakeholders (practitioners and representatives of related authorities). Related issues were discussed through both, separate opinions and dedicated events. For instance, fruitful discussions occurred during the conference (Conference 'Competition rebooted: Enforcement and personal data in digital markets', September 24, 2015). However, discussions continued after the conference as they occurred before the conference.

\footnotetext{
${ }^{1}$ Andrius Puksas, Social Innovations Doctoral School, Research and Innovation Support Centre, Mykolas Romeris University, Vilnius, Lithuania, andrius_puksas@mruni.eu.

${ }^{2}$ Financial sector should be understood in a broad way (not only as a banking sector). Purchasing, online auction platforms also operate with very sensitive data and the additional protection is required.
} 


\section{The Concept of Big Data}

The concept of Big Data appeared together with the growing amounts of information, but this phenomenon caused additional difficulties with data operations. The understanding of Big Data differs, depending on a variety of factors, including the understanding of 'what is big enough' and realizing if 'it is easy to deal with such amount of information.' Taking into account the mentioned features, it is hard to argue with the following definition and provided features, as described by Manyika et al. (2011):

Big Data refers to datasets whose size is beyond the ability of typical database software tools to capture, store, manage, and analyze. This definition is intentionally subjective and incorporates a moving definition of how big a dataset needs to be in order to be considered Big Data - i.e., we don't define Big Data in terms of being larger than a certain number of terabytes (thousands of gigabytes). (p. 1)

The assessment of data is always subjective. In general, this means that, depending on the situation, data can be 'big' for one subject and not for another.

"Big Data refers to the exponential growth both in the availability and in the automated use of information: it refers to gigantic digital datasets held by corporations, governments and other large organisations, which are then extensively analysed (hence the name: analytics) using computer algorithms" (Opinion 03/2013 on Purpose Limitation, 2013). Big Data is 'big' by using at least two parameters: 1) by the amount of information; and 2) by the value of that information. The second parameter is not measured in financial terms only. The information is valuable because it contains important data and can be used by its holder (for instance, to summarize the preferences of customers, to improve the quality of services, and to provide the precise information for a target group). If the information is preserved, it is valuable in one way or another. Otherwise, there is no need to keep the information (the reason being in the resources needed for keeping). "Big Data refers to the practice of companies collecting millions of facts about customers and using those facts to predict trends and develop better sales and marketing strategies" (Payton, Claypoole, \& Schmidt, 2014, p. 7). Hence, the reason Big Data is usually understood as the combination of the two parameters. It is usual to expect that the amount of data depends on the importance of it (data), the sector, and the purpose for its collection. Often, sensitive information has a higher importance. Usually, the information from the medical (health care), financial, law enforcement, and military sectors is presumed more sensitive than data from other informal fields. A list of such sectors is not finite. The first parameter is essential because small fragments of data, that are not Big Data, can also be valuable. In the case of the second parameter, it could be assumed that, for certain reasons, a large volume of outdated information could also be stored.

\section{Interaction of Data Protection and Competition Law}

The growing amount of information raises questions related to new standards for data and market protection. The main problem is not in the data or the amount of the data. Actually, the large assets of information are useful from a practical (for example, adaptation to consumers' needs) and a scientific side (for instance, analyzing data, creating, and developing behavior models). The problem is in the way the data is used and protected.

Some opinions regarding data sharing and its connection in the market raise additional discussions concerning the interaction of data protection and competition law: "As far as competition is concerned, the exchange of information on customer's relationship or applicants reduces the information monopoly of individual lenders and the competitive advantage of large financial institutions" (Ferretti, 2014 , p. 10). Undoubtedly, in the financial sector, demonopolization and sharing of information has a positive impact, especially for the smallest service providers. In the case of 'bad credit records' the scale of positive impact on beneficiaries is larger. However, it is important not to forget that in the case of collected information, the consumers (customers) are and should be protected as a weaker part of the legal relations. The protection of data, especially personal data of the weaker part of legal relations, is understood and seen as a fundamental right of the EU (González-Fuster, 2014). Protection of personal data as a fundamental right of the EU is embodied in Article 8 of Charter of Fundamental Rights of the European Union (2012). Obviously, competition law protecting the single market also 
protects the rights of customers (Zimmer, 2012). Customers are protected from the effects of unfair agreements, abuse of dominant position, and other competition law violations. But from the positions of competition law, even having market control, automatically means a breach of law. Also, large assets of the information (access to Big data) are not automatically held in privacy violation. With privacy protection, the legal acts are dealing with such tools as 'informing about the collection and usage of information', 'asking for permissions', 'targeted usage of collected information', and others.

In general, the content of the EDP Supervisors' Opinion is based on three major steps that are leading discussions, aimed at improving the current interaction among the authorities:

- to understand and spread the message that the amount of information is constantly growing, and in the age of Big Data, there are no 'free services' (usually, personal data is the currency paid for such services);

- to purify and define the harm to customers with relation to the enforcement of competition rules (market power ensured by the access to the information);

- to review and maximize the effectiveness of current relations between data protection and competition law through the wider discussions between the stakeholders and cooperation between responsible authorities.

One of the priorities in the Single Market is to create and maintain the digital single market. It is based on three policy areas (European Commission):

- better online access to digital goods and services;

- an environment where digital networks and services can prosper;

- digital as a driver for growth.

Each of these policy areas has a package of actions which, together with the review of current legislation, should solve the problems mentioned in the Opinion: "A European push is needed to define standards in areas such as the Internet of Things, cybersecurity, Big data and cloud computing" (Digital Single Market, 2016).

Often, the example of the U.S. Federal Trade Commission (2016; FTC) is used to illustrate how the same institution is dealing with two issues that the EDP Supervisor has identified as problematic. However, it should be mentioned that the FTC examines the customer protection and competition issues separately (Feinstein, 2015).

\section{Trends on Enabling Competition Law into Data Protection}

Despite the access to information having influence on the market, there is no issue of competition law when there is no infringement. A strong position in the market (monopolized) can be achieved without distortion of competition. Competition law enforcement appears only in the case where a subject decides to abuse this position. In a speech on January 17, 2016, the European Commissioner for Competition, Margrethe Vestager (Competition in a Big data world - European Commission, 2016), assessed the possibility of enabling competition enforcement for reasonable protection: "I don't think we need to look to competition enforcement to fix privacy problems. But that doesn't mean I will ignore genuine competition issues just because they have a link to data". Taking into account the possible shifts in data protection rules, the Commissioner did not reject such a possibility in the future: "We continue to look carefully at this issue, but we haven't found a competition problem yet. This certainly doesn't mean we never will". The hypothetical option to review current legislation arises when a small numbers of undertakings have an opportunity to benefit from the controlled data (Big Data or large assets of data) and force other undertaking to leave the relevant market. However, such practice has not been encountered.

The EDP Supervisor, in the Opinion 03/2013 on Purpose Limitation (2013, p. 38), stressed the lack of interaction in the development of policies on competition, consumer protection, and data protection, and the importance of "cooperation between authorities in investigation and enforcement, for example in identifying scenarios and possible standards for measuring market power in the digital economy, and consultation on investigations into individual cases". The cooperation between the institutions is ensured through their functions and rights, relating to the execution of delegated functions. During the investigation, institutions communicate on related issues (the right to receive information, which is related with official investigation). Both legislation and case law provides clear standards for market 
power, measured from the position of competition law. It is hard to disagree that "until theories of harm can be matched with specific factual circumstances and negative economic competitive harm can be shown, the antitrust case against Big Data is a weak one" (Sokol \& Comerford, 2016, p. 19).

Separately, the EDP Supervisor in the Opinion 03/2013 on Purpose Limitation (2013) stressed the problem that occurs in the case of company' mergers:

With such a purely economic approach to the case, the Commission did not consider how the merger could have affected the users whose data would be further processed by merging the two companies' datasets, conceivably to provide services, perhaps bundled or even tied to the simple search service, that were not envisaged when the data were originally submitted. (p. 30)

Undoubtedly, in some cases of mergers, there appears a possibility for access to a wider range of data (even about the same person). However, every merger procedure is conducted so that regulation and theoretical problems cannot become a sufficient reason to limit the businesses and prevent their growth. Legislation prevents the market from mergers where the possibility to distort the market appears. In other cases, competition enforcement can be enabled only in the case for breach of competition rules.

Some questions concerning the harm caused by the mergers were answered in separate cases. "The combination of the Google and DoubleClick customer 'databases' is unlikely to provide a considerable additional competitive advantage to the new entity" (European Commission, 2008a, 2008b). After the market analysis, the positive responses (known as permission to complete the merge procedure) were given in the Facebook WhatsApp (European Commission, 2014a, 2014b), Microsoft Skype (European Commission, 2011), Microsoft Nokia (European Commission, 2013), and other cases. In 2014, the Commission's Vice President in charge of competition policy, Joaquín Almunia, commented on the Facebook WhatsApp case, noting that the mentioned acquisition 'would not hamper competition in this dynamic and growing market'. The decision was also supported by such an acquisition having, in general, no hindrance to consumers in accessing a wide choice of similar apps worldwide. However, the data on relevant markets that were analyzed and assessed by the European Commission shows the comprehensiveness of such analysis.

The solution for the problems lies in the development of the digital single market concept and reviewing current legislation on data privacy. However, the question concerning the privacy regulation in digital single market should be answered, and the answer should be provided in the new General Data Protection Regulation (Reform of EU data protection rules, 2016). It is hard to disagree with the statement that the imposing of the privacy regulation may raise the barriers for entering into the market (Antitrust, Privacy, \& Big Data, 2015). It is hard to deny that competition "intervention over market forces threatens consumer welfare, especially is fast moving markets, and proposed remedies, such as limiting the collection and use of Big Data or forcing large firms to share with rivals, are likely to harm competition and innovation, and in fact may raise privacy concerns" (Sokol, 2016, p. 19).

Nevertheless, EU institutions are entitled to cooperate, including with the sharing of data. There are no data to support statements about the lack of cooperation between authorities or refusal to provide relevant information.

\section{Conclusion}

Information and data are understood, not only in their traditional sense, but also as currency, that pay for 'free' services. This currency has it value and in the light of its peculiarities (for instance, sensibility of data and personal importance) and growing amounts, should be protected, with additional possibilities analyzed.

The EDP Supervisors' Opinion revived discussions concerning the interaction between the 'data protection', 'consumer protection', and 'competition.' Regardless of any controversial reaction, the EDP Supervisor achieved one of the Opinions' purposes, aimed at encouraging experts from the relevant fields, national and EU regulators, and other stakeholders into wider debates and discussions. The Opinion was based on emerging threats and new challenges caused by rapidly growing amounts of collected and preserved information. Growing amounts of information encourage the search for additional ways for its protection. There are no doubts that the position in the market can be determined by the content and amount of information. 
The possibility to benefit from the competition law exists, but currently it has not encountered the hypothetical option to review regulation in force. In any relevant market, this could result when minimal undertakings find opportunity to benefit from the controlled data, forcing other "market players' to leave that market.

In the case of mergers, a comprehensive analysis and an assessment of the situation in the relevant markets are conducted. Such an assessment is also provided from the position of the customers (where they are not limited in their choice after the merger). In Google DoubleClick, Facebook WhatsApp, Microsoft Skype, Microsoft Nokia, and other cases, the undertakings were allowed to merge. The data protection is a separate issue.

Digital single market is undergoing the process of protracted reforms. In the projects for legal acts (drafts for future legislation), some problems that were raised in the EDP Supervisors' Opinion have been or should be solved. This meets the opinion that there is no need to make significant changes in the current interaction between the 'data protection', 'consumer protection', and 'competition.' However, there are some problems concerning the role of privacy protection in the digital single market (i.e., possible barriers to entry into the market).

It should be noted that the Opinion of the EDP Supervisor is based on separate facts and definitions from different fields connecting them only through the desire to protect customers from Big Data holders. Undoubtedly, the cooperation between different authorities protecting the objectives of the single market and ensuring the protection of customers' rights should be encouraged. However, there are no objective data claiming that such cooperation does not exist or causes damage for the values protected by legislation.

\section{References}

Antitrust, Privacy \& Big Data. (2015). Concurrences Competition Law Journal [Bulletin]. Retrieved March 23, 2016, from: http://www.cadwalader.com/uploads/media/Concurrences_Cadwalader_-_Antitrust_Big_Data_030215_Synthesis.pdf

Charter of Fundamental Rights of the European Union (2012). OJ C 326, 26.10.2012.

Competition in a Big data world - European Commission (2016, January 17). Retrieved March 21, 2016, from $\mathrm{http} / / /$ ec.europa.eu/commission/2014-2019/vestager/announcements/competition-big-data-world_en

Conference 'Competition rebooted: Enforcement and personal data in digital markets' (2015, September 24). Retrieved March 26, 2016, from

https://secure.edps.europa.eu/EDPSWEB/webdav/site/mySite/shared/Documents/EDPS/Publications/Speeches/2015/15-0924_ERA_GB_EN.pdf

Digital Single Market (2016). Priorities. European Commission. Retrieved March 26, 2016, from http://ec.europa.eu/priorities/digital-single-market_en

EU Data Protection Reform and Big Data Factsheet. (2015, April). Retrieved March 21, 2016, from http://ec.europa.eu/justice/data-protection/files/data-protection-big-data_factsheet_web_en.pdf

European Commission (2008a). Google/ DoubleClick. Case No COMP/M.4731.

European Commission (2008b, March 11). Mergers: Commission clears proposed acquisition of DoubleClick by Google [Press release]. Retrieved March 20, 2016, from http://europa.eu/rapid/press-release_IP-08-426_en.htm

European Commission (2011, October 7). Mergers: Commission approves acquisition of Skype by Microsoft [Press release]. Retrieved March 20, 2016, from http://europa.eu/rapid/press-release_IP-11-1164_en.htm

European Commission (2013, December 4). Mergers: Commission clears acquisition of Nokia's mobile device business by Microsoft [Press release]. Retrieved March 20, 2016, from http://europa.eu/rapid/press-release_IP-13-1210_en.htm

European Commission (2014a). Facebook/ Whatsapp. Case No COMP/M.7217.

European Commission (2014b, October 3). Mergers: Commission approves acquisition of WhatsApp by Facebook [Press release]. Retrieved March 20, 2016, from http://europa.eu/rapid/press-release_IP-14-1088_en.htm

Federal Trade Commission (2016). Retrieved March 20, 2016, from https://www.ftc.gov/

Feinstein, D. (2015, May). Big Data in a Competition Environment. Retrieved March 30, 2016, from https://www.competitionpolicyinternational.com/big-data-in-a-competition-environment/

Ferretti, F. (2014). EU competition law, the consumer interest and data protection: The exchange of consumer information in the retail financial sector. Springer.

González-Fuster, G. (2014). The emergence of personal data protection as a fundamental right of the EU. Springer International Publishing Switzerland.

Manyika, J., Chui, M., Brown, B., Bughin, J., Dobbs, R., Roxburgh, C., \& Hung Byers, A. (2011, May). Big data: The next frontier for innovation, competition, and productivity. Retrieved March 21, 2016, from http://www.mckinsey.com/businessfunctions/business-technology/our-insights/big-data-the-next-frontier-for-innovation 
Opinion 03/2013 on Purpose Limitation. (2013, April 2). Retrieved March 30, 2016, from http://ec.europa.eu/justice/dataprotection/article-29/documentation/opinion-recommendation/files/2013/wp203_en.pdf

Payton, T., Claypoole, T., \& Schmidt, H. A. (2014). Privacy in the age of Big data: Recognizing threats, defending your rights, and protecting your family. Rowman \& Littlefield.

Preliminary Opinion of the European Data Protection Supervisor (2014, March). Privacy and competitiveness in the age of Big data: The interplay between data protection, competition law and consumer protection in the Digital Economy. Retrieved March 21, 2016, from

https://secure.edps.europa.eu/EDPSWEB/webdav/site/mySite/shared/Documents/Consultation/Opinions/2014/14-0326_competitition_law_big_data_EN.pdf

Reform of EU data protection rules (2016, March 20). Retrieved April 03, 2016, from http://ec.europa.eu/justice/dataprotection/reform/index_en.htm

Riefa, C. (2015). Consumer protection and online auction platforms: Towards a safer legal framework. Ashgate Publishing Limited.

Sokol, D. D. \& Comerford, R. E. (2016). Does Antitrust Have a Role to Play in Regulating Big Data? Cambridge Handbook of Antitrust, Intellectual Property and High Tech, Roger D. Blair \& D. Daniel Sokol editors, Cambridge University Press, Forthcoming. Retrieved March 26, 2016, from http://ssrn.com/abstract=2723693

Zimmer, D. (2012). The goals of competition law: Ascola competition law: The fifth ASCOLA Workshop on Comparative Competition Law. Cheltenham: Edward Elgar. 